\title{
Study of the biological and antioxidant activity of $(Z)-2-$ (hydroxybenzylidene)-4,6-dihydroxy-7-methylbenzofuran-3(2H)-ones
}

\author{
(C) Dmitry A. Shubin, ${ }^{1}$ Dmitry N. Kuznetsov, ${ }^{1+*}$ \\ Konstantin I. Kobrakov, ${ }^{1}$ and Valentina V. Martazova ${ }^{2}$ \\ ${ }^{1}$ Department of Organic Chemistry. Russian State University A.N. Kosygin (Technology. Design. Art). \\ Sadovnicheskaya St., 33, p.1. Moscow, 117997.Russia.Phone:+7 (495)811-01-01.E-mail occd@mail.ru \\ ${ }^{2}$ Center for the Transfer of Pharmaceutical Technology. M.V. Dorogova. Technoparkovaya St., 11/2. \\ Yaroslavl, 150064.Russia.Phone:+7 (910)662-76-26.E-mailmkkors@mail.ru
}

\begin{abstract}
*Supervising author; ${ }^{+}$Corresponding author Keywords: methylphloroglucinol, 2,4,6-trihydroxytoluene, benzofuran-3(2H)-one, aurons, antimicrobial activity, antioxidant activity.
\end{abstract}

\begin{abstract}
Studies on the discovery of the chemical potential of 2,4,6-trihydroxytoluene, which has become an affordable reagent in organic synthesis after the development at IPCET SB RAS (Institute for problems of chemical and energetic technologies of the Siberian branch of the Russian academy of sciences) of technology for its preparation from 2,4,6-trinitrotoluene, we have been conducting systematic studies in recent years to obtain it basis of various multifunctional carbo- and heterocyclic compounds. The paper presents the results of a study of the biological and antioxidant activity of hydroxyderivatives of 2-benzylidenebenzofuran-3(2H)ones obtained on the basis of 2,4,6-trihydroxytoluene. The compounds studied in the work showed high inhibitory activity against selected test strains (Escherichia coli, Pseudomonas fluorescens, Staphylococcus aureus, Bacillus subtilis). A study of the fungicidal activity of the synthesized compounds showed that the percentage of suppression of fungal strains (Aspergillus niger, Aspergillus flavus, Penicillium chrysogenum, Ulocladium atrum and Penicillium funiculosum) ranges from $0-20 \%$. The antioxidant properties of the synthesized aurons were studied by cyclic voltammetry on a carbon-metal electrode. Ethanol solutions of rutin and quercetin were used as reference standards. The total antioxidant activity ( $\left.\sum A O A\right)$ was estimated spectrophotometrically using a liquid-phase reaction with a chromophore radical, 2,2'-diphenyl-1picrylhydrazyl (DPPH•), according to the degree of "radical uptake" (P). It was shown that all compounds have moderate antioxidant activity, which depends mainly on the number of hydroxyl groups and their position in the compound molecule. The work shows the value of 4,6-dihydroxy-7-methylbenzofuran-3(2H)one as a building block for combinatorial chemistry.
\end{abstract}

\section{References}

[1] B. Boucherle, M. Peuchmaur, A. Boumendjel, R. Haudecoeu. Occurrences, biosynthesis and properties of aurones as high-end evolutionary products. Phytochemistry. 2017. Vol.142. P.92-111. DOI: 10.1016/j.phytochem.2017.06.017

[2] T. Nakayama, K. Yonekura-Sakakibara, T. Sato, S. Kikuchi, Y. Fukui, M. Fukuchi-Mizutani, T. Ueda, M. Nakao, Y. Tanaka, T. Kusumi, T. Nishino. Aureusidin synthase: a polyphenol oxidase homolog responsible for flower coloration. Science. 2000. Vol.290. No.5494. P.1163-1166. DOI: 10.1126/science.290.5494.1163

[3] R. Haudecoeur, A. Boumendjel. Recent advances in the medicinal chemistry of aurones. Current medicinal chemistry. 2012. Vol.19. No.18. P.2861-2875. DOI: 10.2174/092986712800672085

[4] S. Nigam, B.S. Jayashree. Limitation of Algar-Flynn-Oyamada reaction using methoxy substituted chalcones as reactants and evaluation of the newly transformed aurones for their biological activities. Research on Chemical Intermediates. 2017. Vol.43. No.5. P.2839-2864. DOI: 10.1007/s11164-016$2797-\mathrm{z}$

[5] T.M. Sieleccki, J.F. Boylan, P.A. Benfield, G.L. Trainor. Cyclin-dependent kinase inhibitors: useful targets in cell cycle regulation. Journal of Medicinal Chemistry. 2000. Vol.43. No.1. P.1-18. DOI: $10.1021 / \mathrm{jm} 990256 \mathrm{j}$

[6] O. Kayser, A.F. Kiderlen, U. Folkens, H. Kolodziej. In vitro leishmanicidal activity of aurones. Planta medica. 1999. Vol.65. No.4. P.316-319. DOI: 10.1055/s-1999-13993

Kazan. The Republic of Tatarstan. Russia. (C)Butlerov Communications. 2020. Vol.61. No.2. 
D.A. Shubin, D.N. Kuznetsov, K.I. Kobrakov, and V.V. Martazova

[7] M. Aufmkolk, J. Koerhle, R.D. Hesch, V. Cody. Inhibition of rat liver iodothyronine deiodinase. Interaction of aurones with the iodothyronine ligand-binding site. Journal of Biological Chemistry. 1986. Vol.261. No.25. P.11623-11630.

[8] M. Zhang, X.H. Xu, Y. Cui, L.G. Xie, C.H. Kong. Synthesis and herbicidal potential of substituted aurones. Pest management science. 2012. Vol.68. No.11. P.1512-1522. DOI: 10.1002/ps.3339

[9] A. Detsi, M. Majdalani, C.A. Kontogiorgis, D. Hadjipavlou-Litina, P. Kefalas. Natural and synthetic 2'hydroxy-chalcones and aurones: synthesis, characterization and evaluation of the antioxidant and soybean lipoxygenase inhibitory activity. Bioorganic \& medicinal chemistry. 2009. Vol.17. No.23. P.8073-8085. DOI: $10.1016 /$ j.bmc.2009.10.002

[10] T.T. Huong, N.X. Cuong, H.T. Le, T.T. Quang, V.D. Le, N.H. Nam, N.T. Dat, P.T. Huong, C.N. Diep, P.V. Kiem, C.V. Minh. A new prenylated aurone from Artocarpus altilis. Journal of Asian natural products research. 2012. Vol.14. No.9. P.923-928. DOI: 10.1080/10286020.2012.702758

[11] T. Narsinghani, M.C. Sharma, S. Bhargav. Synthesis, docking studies and antioxidant activity of some chalcone and aurone derivatives. Medicinal Chemistry Research. 2013. Vol.22. No.9. P.4059-4068. DOI: $10.1007 / \mathrm{s} 00044-012-0413-3$

[12] D.A. Shubin, D.N. Kuznetsov, K.I. Kobrakov, A.M. Starosotnikov, N.L. Merkulova. Synthesis of aurone derivatives on the basis of 2,4,6-trihydroxytoluene. Chem. Heterocycl. Compd. 2019. Vol.55. P.1174-1178 DOI: 10.1007/s10593-019-02597-0

[13] R.M. Seabra, A.M.S. Silva, P.B. Andrade, M.M. Moreira. Methylaurones from Cyperus capitatus. Phytochemistry. 1998. Vol.48. No.8. P.1429-1432. DOI: 10.1016/S0031-9422(98)00049-1

[14] URL: http://www.molinspiration.com/cgi-bin/properties (дата обращения: 21.02.2020).

[15] C.A. Lipinski, F. Lombardo, B.W. Dominy, P. Feeney. Experimental and computational approaches to estimate solubility and permeability in drug discovery and development settings. Adv. Drug. Deliv. Rev. 1997. Vol.23. P.3. DOI: 10.1016/S0169-409X(96)00423-1

[16] URL: http://www.pharmaexpert.ru/PASSOnline (дата обращения: 21.02.2020).

[17] URL: http://www.way2drug.com/gusar/acutoxpredict.html (Дата обращения: 21.02.2020).

[18] M.B. Dmitrieva, D.N. Kuznetsov, K.I. Kobrakov, and V.V. Safonov. Effective express method for testing preparations to protect textiles from biological damage. Butlerov Communications. 2013. Vol.33. No.3. P.109-115. ROI: jbc-02/13-33-3-108

[19] V.V. Khasanov, G.L. Ryzhova, E.V. Maltseva. Antioxidant research methods. Chemistry of plant materials. 2004. No.3. P.63-75 (russian).

[20] T.B. Shea, E. Rogers, D. Ashline, D. Ortiz, M.-S. Sheu. Quantification of antioxidant activity in brain tissue homogenates using the 'total equivalent anti-oxidant capacity. Journal of neuroscience methods. 2003. Vol.125. No.1-2. P.55-58. DOI: 10.1016/s0165-0270(03)00028-1

[21] V.A. Smirnov, V.V. Smirnova. Modern methods for measuring the antioxidant activity of biological objects. Almanac of modern metrology. 2015. No.2. P.248-279. (russian)

[22] MUK 4.2.1890-04. Determination of the sensitivity of microorganisms to antibacterial drugs. Methodical instructions. (russian)

[23] CLSI, Methods for Dilution Antimicrobial Susceptibility Tests for Bac-teria that Grow Aerobically, Approved Standard, 9th ed., CLSI document M07-A9, Clinical and Laboratory Standards Institute, 950 West Valley Road, Suite 2500, Wayne, Pennsylvania 19087, USA. 2012.

[24] CLSI, Reference Method for Broth Dilution Antifungal Susceptibility Testing Filamentous Fungi, Approved Standard, 2nd ed., CLSI document M38-A2, 950 West Valley Road, Suite 2500, Wayne, Pennsylvania 19087, USA. 2008. 